\title{
Taraxacum officinale and Urtica dioica extracts inhibit dengue virus serotype 2 replication in vitro
}

\author{
María R. Flores-Ocelotl1,2,3, Nora H. Rosas-Murrieta ${ }^{4}$, Diego A. Moreno ${ }^{5}$, Verónica Vallejo-Ruiz ${ }^{1}$, Julio Reyes-Leyva ${ }^{1}$,
} Fabiola Domínguez ${ }^{2^{*}}$ and Gerardo Santos-López ${ }^{1 *}$ (D)

\begin{abstract}
Background: Urtica dioica, Taraxacum officinale, Calea integrifolia and Caesalpinia pulcherrima are widely used all over the world for treatment of different illnesses. In Mexico, these plants are traditionally used to alleviate or counteract rheumatism and inflammatory muscle diseases. In the present study we evaluated the activity of aqueous and methanolic extracts of these four plants, on the replication of dengue virus serotype 2 (DENV2).
\end{abstract}

Methods: Extraction process was carried out in a Soxtherm ${ }^{\oplus}$ system at 60,85 and $120^{\circ} \mathrm{C}$; a chemical fractionation in silica gel chromatography was performed and compounds present in the active fractions were identified by HPLC-DAD-ESI/MSn. The cytotoxic concentration and the inhibitory effect of extracts or fractions on the DENV2 replication were analyzed in the BHK-21 cell line (plaque forming assay). The half maximal inhibitory concentration $\left(\mathrm{IC}_{50}\right)$ and the selectivity index (SI) were calculated for the extracts and fractions.

Results: The methanolic extracts at $60^{\circ} \mathrm{C}$ of $T$. officinale and U. dioica showed the higher inhibitory effects on DENV2 replication. After the chemical fractionation, the higher activity fraction was found for U. dioica and T. officinale, presenting $I_{50}$ values of $165.7 \pm 3.85$ and $126.1 \pm 2.80 \mu \mathrm{g} / \mathrm{ml}$, respectively; SI values were 5.59 and 6.01 for each fraction. The compounds present in $T$. officinale, were luteolin and caffeoylquinic acids derivatives and quercertin diclycosides. The compounds in the active fraction of U. dioica, were, chlorogenic acid, quercertin derivatives and flavonol glycosides (quercetin and kaempferol).

Conclusions: Two fractions from U. dioica and T. officinale methanolic extracts with anti-dengue activity were found. The compounds present in both fractions were identified, several recognized molecules have demonstrated activity against other viral species. Subsequent biological analysis of the molecules, alone or in combination, contained in the extracts will be carried out to develop therapeutics against DENV2.

Keywords: Taraxacum officinale, Urtica dioica, Calea integrifolia, Caesalpinia pulcherrima, Dengue virus, Antiviral

\section{Background}

Dengue fever is a viral disease transmitted by mosquitoes in the genus Aedes, the principal species are A. aegypti and $A$. albopictus. The infection occurs mainly in tropical and subtropical regions of the planet. The number of cases

\footnotetext{
*Correspondence: irmafabiola@yahoo.com; gerardo.santos.lopez@gmail.com ${ }^{2}$ Laboratorio de Biotecnología de Productos Naturales, Centro de Investigación Biomédica de Oriente, Instituto Mexicano del Seguro Social, Km 4.5 Carretera Federal Atlixco-Metepec, CP 74360 Metepec, Puebla, México ${ }^{1}$ Laboratorio de Biología Molecular y Virología, Centro de Investigación Biomédica de Oriente, Instituto Mexicano del Seguro Social, Km 4.5 Carr Federal Atlixco-Metepec, 74360 Metepec, Puebla, México

Full list of author information is available at the end of the article
}

in the past 30 years has increased considerably, this disease affects more than 100 countries around the world with 100 million cases each year, 500 thousand requiring hospitalization, and approximately 25,000 resulting in death each year [1-3].

Dengue virus (DENV), a member of the Flaviviridae family, is an enveloped virus containing a $\sim 11 \mathrm{~kb}$ genome of positive single-stranded RNA which encodes three structural proteins $(\mathrm{C}, \mathrm{pr}-\mathrm{M}, \mathrm{E})$ and seven nonstructural proteins (NS1, NS2A, NS2B, NS3, NS4A, NS4B, NS5) [4]. Four serotypes of dengue virus (DENV1, DENV2, DENV3 and DENV4) cause dengue 
fever (DF) and more severe manifestations like dengue hemorrhagic fever (DHF) and dengue shock syndrome (DSS) [1].

Currently there are no specific antiviral compounds for the treatment, however, several research groups have sought antiviral compounds by molecular docking $[5,6]$ or using medicinal plants to inhibit a viral target $[7,8]$. Current treatment to severe dengue is supportive fluid therapy under medical supervision [9]. Having no specific antiviral therapy or an antiviral agent for dengue treatment, different methods for prevention have been established by controlling the mosquito reproduction or spread $[10,11]$. Due to the lack of new molecules, some clinical researches have proposed the repurposing of well-known drugs such as chloroquine, prednisolone, balapiravir, celgosivir, and lovastatin, however, although those drugs are safe, they have not been successful at decreasing viral load, antigenemia, fever or inducing a beneficial effect to dengue patients [12].

Ethnopharmacology has contributed significantly to the discovery of new drugs $[13,14]$. In recent years, the focus on medicinal plants widely used in traditional systems has increased worldwide [15]. Based on ethnobotanical information some studies have demonstrated several compounds with anti-dengue potential activity such as, 7-0-methyl-glabranine [16], baicalein [17], catanospermine [7], quercetin and fisetin [18, 19].

Within the Mexican population, dengue is commonly known as "five-day fever", "breakbone fever" or simply "breaker". For the treatment of this disease there are therapeutic resources of traditional medicine, whose information has been collected over many years in important databases such as the Medicinal Herbarium of the Mexican Social Security Institute (Herbarium IMSS-M) [20]. In this collection, multiple uses of medicinal plants native to Mexico are referenced, including some that have traditionally been used against dengue, such as Taraxacum officinale, Urtica dioica, Calea integrifolia and Caesalpinia pulcherrima.

These plants are widely used in traditional medicine around the world for the treatment of many illnesses. $U$. dioica has great medicinal potential, its extracts have been used for the treatment of eczema, digestion, pain, anemia, arthritis, rheumatism [21], and it inhibits inflammatory processes caused by seasonal allergies [22]. T. officinale is used in the treatment of anemia, liver cirrhosis, rheumatoid arthritis and also it has been reported with anti-inflammatory, anti-oxidative, anti-carcinogenic, analgesic, anti-hyperglycemic, laxative and diuretic activities and also as stimulating for the digestive system [23]. It was reported that $T$. officinale has inhibitory potential against HIV and its reverse transcriptase [24].

C. pulcherrima is used in the treatment of cough [25], contains flavonoids and some reports show that aqueous extracts of flowers, leaves and stem, have inhibitory effect on several viruses, including herpes (HSV1-2) and adenoviruses (ADV-3, ADV-8, ADV-11) [26]. Meanwhile, $C$. integrifolia has been reported with antihyperglycemic activity and used in the treatment of diabetes $[27,28]$.

Of these plant species, only U.dioica has been reported as a source of an anti-dengue constituent, since the N-AcetylD-Glucosamine-specific lectin of this plant (UDA) has proved effective at reducing the viral infection of the four dengue serotypes [29]. However, other compounds, distinct from proteins have not been studied. Therefore, in this work it was analyzed if the aqueous and methanolic extracts of these four plants have inhibitory activity on DENV2 replication.

\section{Methods \\ Reagents}

Solvents methanol, ethyl acetate, formic acid and dimethyl sulfoxide (DMSO) reagent or HPLC grade and silica gel (Kiselgel 69) were obtained from Merck KGaA (Darmstadt, Germany). Media and supplements for cell culture were purchased from Sigma-Aldrich Chemicals (St. Louis, MO, USA) and molecular grade agarose was obtained from Promega (Madison, USA). All other reagents used in analytical methods were purchased from Sigma-Aldrich Chemicals, except where otherwise indicated.

\section{Cells}

C6/36 cell line (A. albopictus) was maintained in minimum essential medium (MEM) supplemented with 5\% fetal bovine serum (FBS), $100 \mathrm{U} / \mathrm{mL}$ penicillin, $100 \mu \mathrm{g} /$ $\mathrm{mL}$ streptomycin. Cell line BHK-21 (hamster kidney neonate) was cultured in MEM supplemented with 5\% FBS and antibiotics. Cells were incubated at $37{ }^{\circ} \mathrm{C}$ in $5 \%$ $\mathrm{CO}_{2}$. As is recommended for this type of experiments, Aedes albopictus C6/36 cells (ATCC: CRL-1660) were used for viral propagation [30] and baby hamster kidney BHK-21 cells (ATCC: CCL-10) were used to quantify the virus by plaque reducing assays $[7,31]$.

\section{Virus}

Dengue virus serotype 2 (DENV2) strain Thailand/ $16681 / 1984$ used in this study was kindly provided by Dr. Alvaro Aguilar-Setien (IMSS, Mexico City, Mexico). To obtain the inoculum used in all experiments, dengue virus was replicated in C6/36 cells for 5 days. Subsequently the viral supernatant was centrifuged for $5 \mathrm{~min}$ at $10,000 \mathrm{rpm}$ to remove the cell debris. Aliquots were stored at $-70{ }^{\circ} \mathrm{C}$ until use $[32,33]$.

\section{Viral titration}

Infection of the cells by DENV2 was confirmed by reverse transcription-polymerase chain reaction (RT-PCR) 
using reported specific primers [34] and by immunofluorescence using an antibody against the viral prM protein, as previously reported by our group [32, 33]. Quantification of DENV2 was performed by the lytic plaque assay in BHK-21 cells on six wells plates; after $24 \mathrm{~h}$, the cells were washed with PBS and infected with 10 -fold serial dilutions of the virus inoculum. After $1 \mathrm{~h}$, the not absorbed virus was removed, cells were washed with PBS and then 0.35\% agarose and DMEM were added. Plates were incubated for $72 \mathrm{~h}$ at $4{ }^{\circ} \mathrm{C}$ and $5 \%$ $\mathrm{CO}_{2}$. After that, $5 \%$ trichloroacetic acid was used to fix the cells and subsequently they were stained with $0.05 \%$ crystal violet in $20 \%$ ethanol [32, 33, 35].

\section{Selection and collection of medicinal plants}

The plant species $T$. officinale, $U$. dioica, $C$. integrifolia and C. pulcherrima used in this study were identified as likely sources of active compounds against dengue virus from ethnobotanical information obtained from Herbarium IMSS-M (Catalogs: 1988, 1990, 1994; available in paper format only), which concerns its use in syndromes or diseases which are probably dengue, such as inflammatory muscle pain. All the plant specimens were collected in the state of Puebla, Mexico, in the municipalities of San Jeronimo Tecuanipan (19 $00^{\prime} 00^{\prime \prime}$ North, $98^{\circ} 24^{\prime} 54^{\prime \prime}$ West) and in Atlixco (18 $54^{\prime} 45^{\prime \prime}$ North, $98^{\circ} 25^{\prime} 40^{\prime \prime}$ West). The aerial part of the plants was cropped with contaminant-free cutter and transported to the laboratory. The vegetal material was taxonomically identified by experts of the Herbarium IMSS-M at Mexico City and reference vouchers of the plants material T. officinale, $U$. dioica, C. integrifolia and C. pulcherrima were deposited with the codes IMSS-M 164320, 164340, 17080 and 17120, respectively.

\section{Processing of plants and obtaining of crude extracts}

Leaves of each plant were separated, washed and air-dried at room temperature $\left(26^{\circ} \mathrm{C}\right)$ for 2 weeks, after which they were grinded to a uniform powder in a blender (Nutribullet LLC, Pacoima, CA, USA). The extraction from pulverized plants was conducted in a Soxtherm ${ }^{\circ}$ system (Gerhardt, Königswinter, Germany) at 60,85 and $120^{\circ} \mathrm{C}$ using methanol or water as solvents. In the extraction process the variables were the solvents and the extraction temperatures, but the extraction time (60 $\mathrm{min})$, the reduction range (30 s) and the pulse reduction ( $2 \mathrm{~s}$ ) remained constant. Methanolic and aqueous extracts were dried using a rotary evaporator (Heidolph Instruments Gmbh \& Co. KG, Germany) at $60{ }^{\circ} \mathrm{C}$ or $90^{\circ} \mathrm{C}$, respectively. The dried residue was weighed, dissolved in DMSO [17] and used for cytotoxicity and inhibition of viral replication tests.

\section{Determination of cytotoxicity}

The cytotoxic concentration $50\left(\mathrm{CC}_{50}\right)$ was obtained in BHK-21 cells with the conventional MTT (3-(4,5- dimethylthiazol-2-yl)-2,5-diphenyltetrazolium bromide) colorimetric assay by serial dilutions (between 0.1 and $1200 \mu \mathrm{g} / \mathrm{ml}$ ) of the extracts in DMSO, used as vehicle to all extracts or fractions. After 3 days of incubation at $37{ }^{\circ} \mathrm{C}$ and $5 \% \mathrm{CO}_{2}$, the culture medium was removed, the cells were washed twice with PBS and the standard MTT protocol was performed [36]. Experiments were carried out in triplicate and done twice.

\section{Viral inhibition assays}

BHK-21 cells were seeded in 6-wells plates during $24 \mathrm{~h}$. The infection was performed with $0.5 \mathrm{ml}$ of DENV inoculum in a dilution to produce approximately 100 lytic plaques per well (a 1:3100 dilution from a titrated viral inoculum at $3.1 \mathrm{X} 10^{6} \mathrm{PFU} / \mathrm{ml}$ ). After $1 \mathrm{~h}$ incubation, the viral inoculum was removed and washed with PBS twice. Immediately, different concentrations of each of the extracts were added. As control for inhibition the study used: a) cells without extract and without infection, b) infected cells without extract and, c) cells without infection and with extract [37]. Subsequently molecular biology grade agarose was added to a final concentration of $0.35 \%$ in DMEM with $2.5 \%$ FBS. After 3 days, the cells were fixed with 10\% trichloroacetic acid for $10 \mathrm{~min}$ and stained with $0.1 \%$ crystal violet for $3 \mathrm{~min}$. Results of the inhibition of viral replication were reported as a percentage of the formed lytic plaques compared to the control infection assay (100\%), which was not treated with plant extracts [32,33]. Experiments were carried out in triplicate and done twice.

\section{Chromatographic fractionation}

$T$. officinale and $U$. dioica extracts were fractionated. The extracts were suspended in deionized water and partitioned twice with dichloromethane and the solvents were exhaustively removed to obtain dichloromethane fraction. This fraction was subjected to silica gel column $(10 \times 30 \mathrm{~cm})$ and eluted with a gradient of n-hexaneethyl acetate $(9: 1,8: 2, \ldots 1: 1)$ to yield 17 fractions. These fractions were evaluated in the same biologic assays.

\section{Identification of compounds by HPLC-DAD-ESI/MSn}

For the chemical analysis, $100 \mathrm{mg}$ of sample were mixed with $1.5 \mathrm{~mL}$ of methanol:water:formic acid (25:24:1, $\mathrm{v}: \mathrm{v}: \mathrm{v})$ extractant, then vortexed and sonicated in an ultrasonic bath for $60 \mathrm{~min}$ at room temperature. The samples were kept at $4{ }^{\circ} \mathrm{C}$ overnight and sonicated again for $60 \mathrm{~min}$. A centrifugation was performed for $10 \mathrm{~min}$ at $10,000 \mathrm{rpm}$ to separate the supernatant from the solid residue. The supernatant was filtered through a $0.22 \mu \mathrm{m}$ PVDF filter before analysis (Millipore, MA, USA). The chromatographic analyses for identification of compounds were carried out on a Luna C18 column $(250 \times 4.6 \mathrm{~mm}$, $5 \mu \mathrm{m}$ particle size; Phenomenex, Macclesfield, UK). 
Water/formic acid (99:1, $v / v)$ and acetonitrile were used as the mobile phases $\mathrm{A}$ and $\mathrm{B}$, respectively, with a flow rate of $1 \mathrm{~mL} / \mathrm{min}$. The linear gradient started with $8 \%$ solvent $\mathrm{B}$, reaching $15 \%$ solvent $\mathrm{B}$ at $25 \mathrm{~min}, 22 \%$ at $55 \mathrm{~min}$, and $40 \%$ at $60 \mathrm{~min}$, which was maintained to $70 \mathrm{~min}$. The injection volume was $20 \mu \mathrm{L}$, and the analyses were carried out using an Agilent HPLC 1100 series model equipped with a photodiode array detector and a mass detector in series (Agilent Technologies, Waldbronn, Germany). The equipment consisted of a binary pump (model G1312A), an autosampler (model G1313A), a degasser (model G1322A), and a photodiode array detector (model G1315B). The HPLC system was controlled by ChemStation software (Agilent, version 08.03). The mass detector was an ion trap spectrometer (model G2445A) equipped with an electrospray ionization interface, and was controlled by LCMSD software (Agilent, version 4.1). The ionization conditions were $350{ }^{\circ} \mathrm{C}$ and $4 \mathrm{kV}$, for capillary temperature and voltage, respectively. The nebulizer pressure and nitrogen flow rate were $65.0 \mathrm{psi}$ and $11 \mathrm{~L} / \mathrm{min}$, respectively. The fullscan mass covered the range of $\mathrm{m} / \mathrm{z}$ from 100 to 1200 . Collision-induced fragmentation experiments were performed in the ion trap using helium as the collision gas, with voltage ramping cycles from 0.3 to $2 \mathrm{~V}$. The mass spectrometry data were acquired in the positive ionization mode for anthocyanins and in the negative ionization mode for other flavonoids. The MSn was carried out in the automatic mode on the more-abundant fragment ion in MS (n-1).

\section{Statistical analysis}

To calculate cytotoxicity $\left(\mathrm{CC}_{50}\right)$ and lytic plaques reduction $\left(\mathrm{IC}_{50}\right)$ the GraphPadPrism program (Software, San Diego, CA.) was used. The selectivity index (SI) was calculated by the ratio of the value of $\mathrm{CC}_{50} / \mathrm{IC}_{50}$.

\section{Results}

\section{Obtaining the plant extracts}

Extracts of four plant species at three distinct temperatures using two solvents were obtained. Each extract was performed in triplicate; therefore, 72 final individual extracts were evaluated.

\section{Cytotoxicity of plant extracts}

The cytotoxicity $\left(\mathrm{CC}_{50}\right)$ values were in the range of 200 to $1100 \mu \mathrm{g} / \mathrm{mL}$. The most toxic extract was of C. pulcherrima obtained with methanol at $60{ }^{\circ} \mathrm{C}(241.03 \pm 9.93 \mu \mathrm{g} / \mathrm{mL})$, while the less toxic was of $T$. officinale obtained with methanol at $120{ }^{\circ} \mathrm{C}(1,013.45 \pm 33.84 \mu \mathrm{g} / \mathrm{mL})$. Results for all extracts are shown in Tables 1 and 2. Considering the cytotoxic potential, working concentrations below the $\mathrm{CC}_{50}$ were defined to evaluate the antiviral activity.
Table 1 Cytotoxic concentration $50\left(C_{50}\right)$ of the aqueous extracts to 60,85 and $120^{\circ} \mathrm{C}$

\begin{tabular}{llll}
\hline & \multicolumn{3}{l}{$\mathrm{CC}_{50}(\mu \mathrm{g} / \mathrm{ml})$} \\
\cline { 2 - 4 } & $60{ }^{\circ} \mathrm{C}$ & $85^{\circ} \mathrm{C}$ & $120^{\circ} \mathrm{C}$ \\
\hline T. officinale & $617.26 \pm 23.62$ & $762.50 \pm 27.79$ & $675.63 \pm 29.80$ \\
U. dioica & $373.78 \pm 22.77$ & $448.68 \pm 26.99$ & $493.43 \pm 10.26$ \\
C. integrifolia & $876.18 \pm 29.62$ & $926.31 \pm 40.89$ & $991.47 \pm 35.00$ \\
C. pulcherrima & $719.07 \pm 23.10$ & $904.56 \pm 23.54$ & $941.42 \pm 29.10$ \\
\hline
\end{tabular}

The aqueous extracts have low potential to inhibit the viral infection

The inhibitory activity on DENV2 infection in cell culture was different with each of the extracts, which were tested between 25 and $200 \mu \mathrm{g} / \mathrm{mL}$. The aqueous extracts showed little inhibition potential, for example, C. pulcherrima, $U$. dioica and $C$. integrifolia decreased the infection level between 5 and $10 \%$ at $200 \mu \mathrm{g} / \mathrm{mL}$. The aqueous extract with higher activity against DENV was obtained for T. officinale at $60{ }^{\circ} \mathrm{C}$, which caused $53 \%$ inhibition at the maximum tested concentration $(200 \mu \mathrm{g} / \mathrm{mL})$. None of the other extracts decreased more than $50 \%$ the number of lytic plaques produced by the virus (data not shown). None of the aqueous extracts were used in subsequent studies.

\section{Methanolic extracts of $T$. officinale and $U$. dioica inhibit the replication of DENV2}

The methanolic extracts at $60{ }^{\circ} \mathrm{C}$ of all the four plants, inhibited the viral replication in a dose-dependent manner. However, only $T$. officinale and $U$. dioica extracts reach more than $50 \%$ inhibition of the lytic plaques, therefore only for them the $\mathrm{IC}_{50}$ was calculated and were $132.50 \pm 3.25$ and $74.5 \pm 1.70 \mu \mathrm{g} / \mathrm{ml}$, respectively (the SI values were 7.31 and 9.43 for each extract) (Table 3, Fig. 1). Figure 2 shows some examples of the inhibition of lytic plaques with methanolic extracts at $60{ }^{\circ} \mathrm{C}$ of the four tested plants.

The extracts obtained at $85{ }^{\circ} \mathrm{C}$ showed also inhibition properties (Fig. 1b) and the $\mathrm{IC}_{50}$ values were calculated as $179.1 \pm 6.56$ and $194.7 \pm 3.65 \mu \mathrm{g} / \mathrm{mL}$ for $T$. officinale and $U$. dioica, respectively (Table 3, Fig. 1). The rest of the extracts obtained at $85{ }^{\circ} \mathrm{C}$ decreased the viral infection only slightly. The extracts obtained at $120{ }^{\circ} \mathrm{C}$ of the

Table 2 Cytotoxic concentration $50\left(\mathrm{CC}_{50}\right)$ of the methanolic extracts to 60,85 and $120^{\circ} \mathrm{C}$

\begin{tabular}{llll}
\hline & \multicolumn{3}{l}{$\mathrm{CC}_{50}(\mathrm{\mu g} / \mathrm{ml})$} \\
\cline { 2 - 4 } & $60{ }^{\circ} \mathrm{C}$ & $85{ }^{\circ} \mathrm{C}$ & $120{ }^{\circ} \mathrm{C}$ \\
\hline T. officinale & $968.38 \pm 37.17$ & $891.92 \pm 29.19$ & $1013.45 \pm 33.84$ \\
U. dioica & $702.50 \pm 14.50$ & $669.15 \pm 17.13$ & $830.07 \pm 18.20$ \\
C. integrifolia & $758.78 \pm 20.33$ & $715.02 \pm 16.17$ & $745.18 \pm 21.88$ \\
C. pulcherrima & $241.03 \pm 9.93$ & $325.09 \pm 14.34$ & $344.17 \pm 13.24$ \\
\hline
\end{tabular}


Table 3 Half maximal inhibitory concentration $\left(\mathrm{IC}_{50}\right)$ and selectivity index (SI) on DENV2 replication of methanolic extracts at 60 and $85{ }^{\circ} \mathrm{C}$ and the $T$. officinale and $U$. dioica fractions obtained by silica gel chromatography

\begin{tabular}{llll}
\hline & $\mid C_{50}(\mu \mathrm{g} / \mathrm{ml})$ & $\mathrm{CC}_{50}(\mu \mathrm{g} / \mathrm{ml})$ & $\mathrm{SI}$ \\
\hline T. officinale $\left(60^{\circ} \mathrm{C}\right)$ & $132.50 \pm 3.25$ & $968.38 \pm 37.17$ & 7.31 \\
U. dioica $\left(60^{\circ} \mathrm{C}\right)$ & $74.51 \pm 1.70$ & $702.50 \pm 14.50$ & 9.43 \\
T. officinale $\left(85^{\circ} \mathrm{C}\right)$ & $179.1 \pm 6.56$ & $891.92 \pm 29.19$ & 4.98 \\
U. dioica $\left(85^{\circ} \mathrm{C}\right)$ & $194.7 \pm 3.63$ & $669.15 \pm 17.13$ & 3.44 \\
T. officinale $\mathrm{F}-09^{\mathrm{a}}$ & $165.70 \pm 3.85$ & $925.45 \pm 29.27$ & 5.59 \\
U. dioica F-07 & $126.10 \pm 2.80$ & $758.25 \pm 24.75$ & 6.01 \\
\hline
\end{tabular}

$\mathrm{SI}$ was calculated by the formula: $\mathrm{CC}_{50} / \mathrm{CC}_{50}$

${ }^{\text {a }}$ Fraction number obtained by chromatography

four plants showed no consistent inhibitory effect on the formation of lytic plaques (Fig. 1c).

\section{Antiviral activity of $T$. officinale and $U$. dioica extracts fractioned by silica gel chromatography}

Extracts of $T$. officinale and $U$. dioica obtained with methanol at $60{ }^{\circ} \mathrm{C}$ were fractioned. Seventeen fractions for every extract were obtained. All fractions were tested to identify antiviral activity and to quantify their cytotoxicity. The higher antiviral activity was identified in the fractions (F) 9 and 7 of $T$. officinale and $U$. dioica, respectively. In separate assays, both F9 and F7 inhibited the DENV2 replication in a dose-dependent manner. The calculated $\mathrm{IC}_{50}$ value for $T$. officinale was $165.70 \pm$ 3.85 and for $U$. dioica was $126.10 \pm 2.80 \mu \mathrm{g} / \mathrm{ml}$, while SI values were 5.59 and 6.01, respectively (Table 3, Fig. 3).

\section{Compounds identified in $T$. officinale F9}

Analysis of $T$. officinale F9 showed major peaks of phenolic metabolites that have been previously reported in literature and were characterized by HPLC-PDA-ESI-MS/MS (negative ionization mode) as presented in Table 4, besides other compounds present in lesser amounts.

The compound 1 was characterized as caffeoyl hexoside $(\mathrm{m} / \mathrm{z}$ 341) which showed the loss of a saccharide moiety in the MS2 (162 Da). The caffeoylquinic acid (CQA) was characterized by means of -MS2 of its deprotonated molecular ion $(\mathrm{m} / \mathrm{z} 353)$ giving a base peak at $\mathrm{m} / \mathrm{z} 191$, and the $\mathrm{m} / \mathrm{z} 179$ ion is weak or undetectable, and according to Clifford et al., [38] can be labeled as 5caffeoylquinic acid (5-CQA) (2). Additionally, caffeic acid (3) and di-caffeoylquinic acids (di-CQA) ([M-H]-, $\mathrm{m} / \mathrm{z} 515$ ) were also present (13 and 14).

Besides caffeoylquinic acids, two dicaffeoyltartaric acid derivatives were detected. Both components (10 and 11), showed $[\mathrm{M}-\mathrm{H}]$ ion at $\mathrm{m} / \mathrm{z} 473$ and the formation of a predominant product ion at $\mathrm{m} / \mathrm{z} 311$ (loss of a caffeoyl moiety). In the MS2 and MS3 experiment the loss of a second caffeic acid moiety was observed, resulting in a

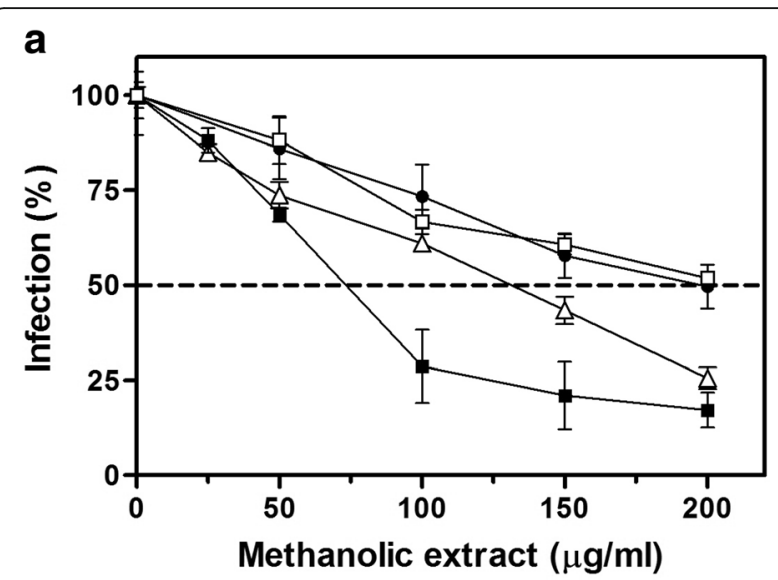

b

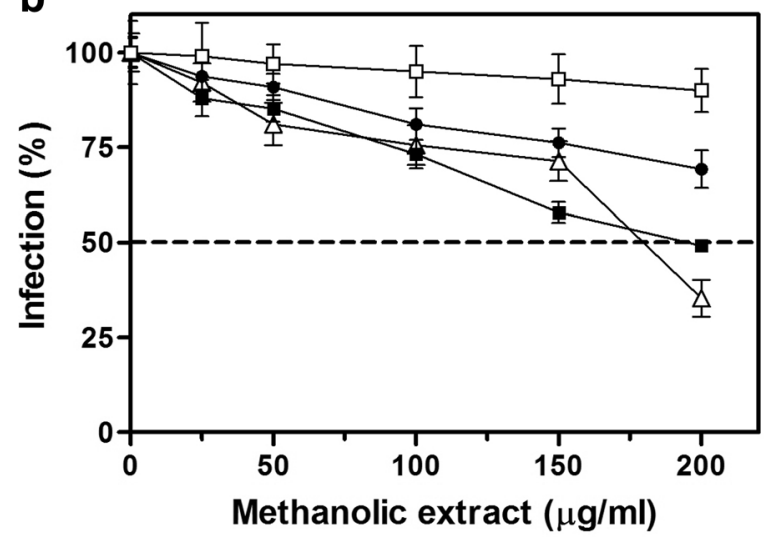

C

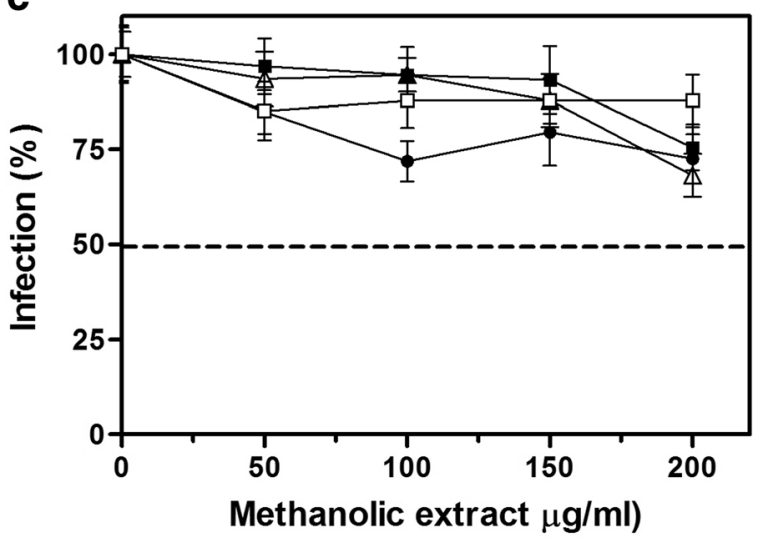

$\begin{array}{ll}\triangle \text { Taraxacum officinale } & \rightarrow \text { Calea intearifolia } \\ \rightarrow-\text { Urtica dioica } & \rightarrow-\text { Caesalpinia pulcherrima }\end{array}$

Fig. 1 Effect of methanolic plant extracts on the DENV replication in cell culture. Methanolic extracts at $60(\mathbf{a}), 85(\mathbf{b})$ and $120^{\circ} \mathrm{C}(\mathbf{c})$ of $U$. dioica, T. officinale, C. integrifolia and C. pulcherrima were tested in order to inhibit the replication in vitro of DENV2

base peak at $\mathrm{m} / \mathrm{z}$ 149. Since this fragmentation was already reported, it is concluded that these compounds are chicoric acids, also present in lettuces [39].

With respect to the flavonoids, in the UV chromatogram hydroalcoholic extracts we have detected seven 

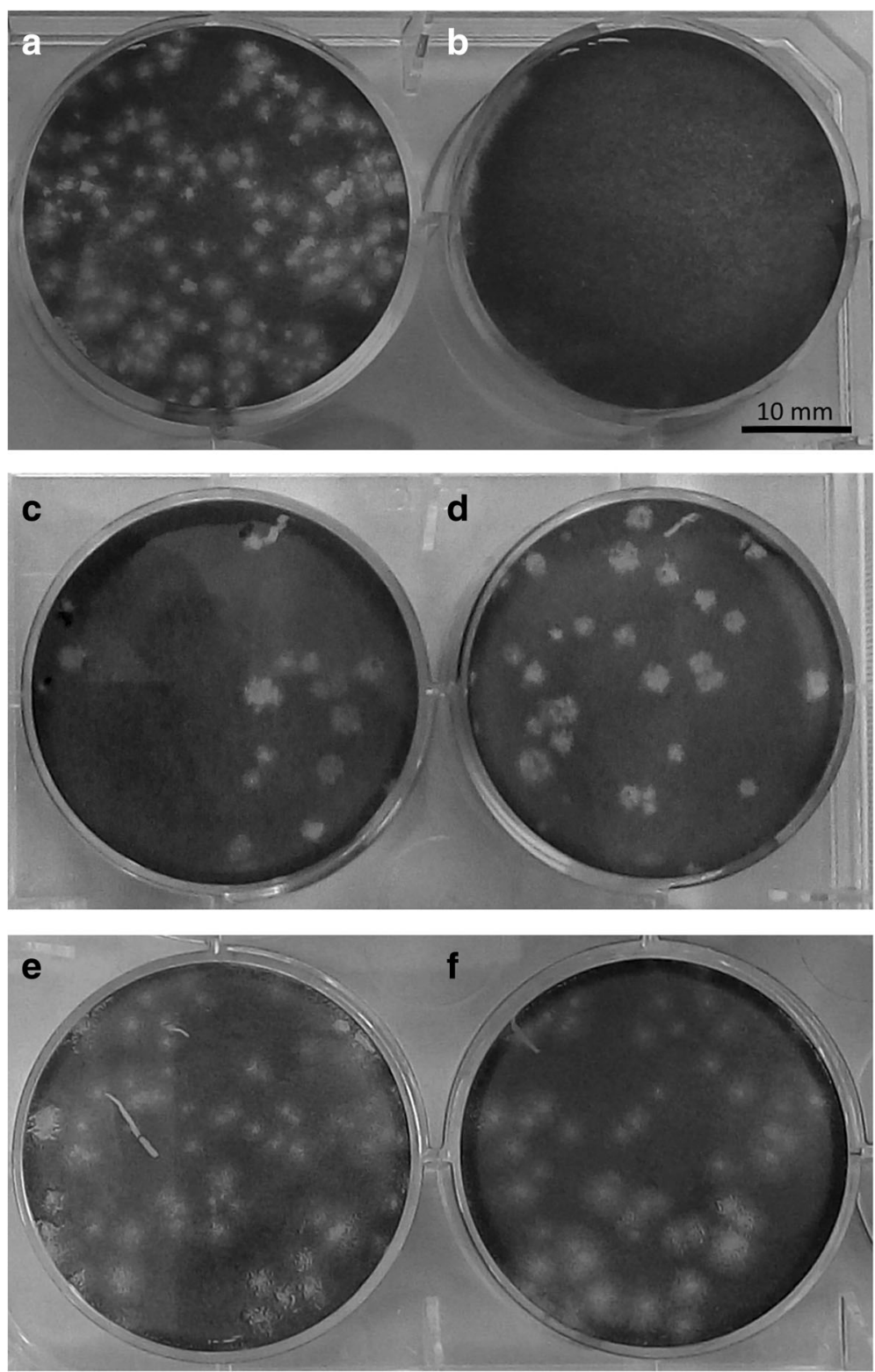

Fig. 2 Inhibiting the formation of lytic plaques using methanolic extracts at $60^{\circ} \mathrm{C}$. DENV infection in BHK21 cells were inhibited incubating the plant extracts with every extract before the infection assay. Effect of $200 \mu \mathrm{g} / \mathrm{ml}$ of U. dioica (c), T. officinale (d), C. integrifolia (e) and C. pulcherrima (f) extracts are shown. Non-inhibited and non-infected controls are shown in $\mathbf{a}$ and $\mathbf{b}$, respectively

compounds (4-9 and 12). The compounds 4 and 5 provided $[\mathrm{M}-\mathrm{H}]$ ions at $\mathrm{m} / \mathrm{z} 595$, and MS2 and MS3 fragmentations for a quercertin diglycoside with a pentose and a hexose moiety linked in distinct positions of the aglycone $(\mathrm{m} / \mathrm{z} 463,301)$.

The compound 7 showed UV spectra of quercetin derivative [40] and deprotonated molecular ion at m/z 609 . Its MS2 fragmentation gave the unique peak at $\mathrm{m} / \mathrm{z} 301$ corresponding to the deprotonated ion of its aglycon, as well as absence of intermediate ions, indicating a interglycosidic linkage rhamnosyl $(1 \rightarrow 6)$ glucoside, (rutinoside) [41]. All these data indicate that this compound is
quercetin-3-O-rutinoside (rutin), widely distributed in plants. F9 also presented several luteolin glycosides $(6,8$, 9 , and 12), showing a prominent fragment at $\mathrm{m} / \mathrm{z} 285$. The order of elution and identities were assigned according to the previous reports of the presence of these compounds in dandelion [39].

\section{Compounds identified in U. dioica F7}

According to the results of the LC-MS analyses and major fragments in MS2 (ESI negative mode), there were not any gallic acid, syringic, fumaric, vanillic, isorhamnetin or flavanols in the samples, but there were 


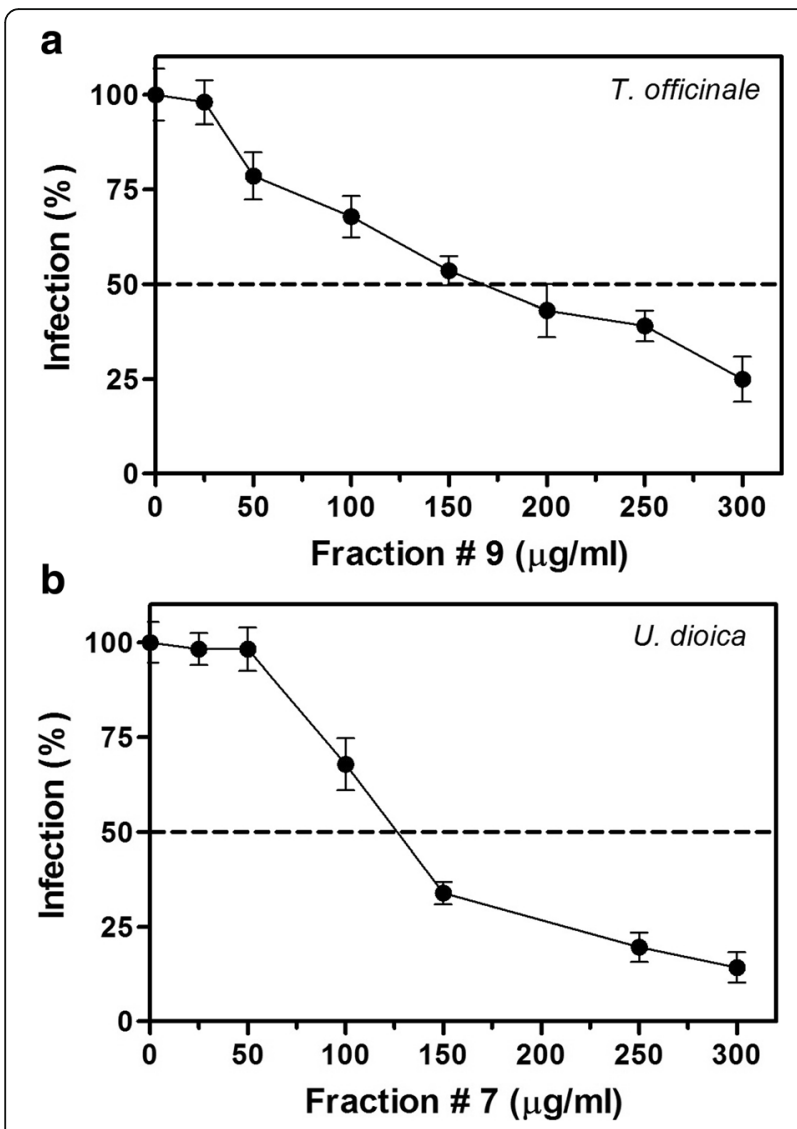

Fig. 3 Antiviral activity of fractions 7 and 9 of $T$. officinale (a) and $U$. dioica (b) extracts obtained by silica gel chromatography chlorogenic acid $(353 \mathrm{~m} / \mathrm{z})$, rutin $(609 \mathrm{~m} / \mathrm{z})$, and flavonol glycosides (e.g. quercetin and kaempferol glycosides, with 463 and $447 \mathrm{~m} / \mathrm{z}$, respectively) (Table 5).

\section{Discussion}

Multiple studies have reported the discovery or obtaining of compounds with anti-dengue properties $[8,16-18,29$, 42-47], however, up to now there are no commercially available drugs for treatment of dengue.

In the present study we included plants widely used in traditional medicine in many countries for the treatment of many diseases or organic disorders [48, 49]. Extracts from our selected plants presented different activities per species, temperature and solvent used. The lesser toxic extract was $T$. officinale obtained with methanol and the more toxic was the methanolic extract obtained from C. pulcherrima.

We performed a protocol in which the cells were infected and subsequently, the plant extract was added as possible inhibitor, trying to simulate a system with an active DENV infection, like it occurs in a natural infection. Therefore, this protocol suggests that the inhibitory effect of virus replication is obstructed in an intermediate step in the replication cycle, similar to what has been reported in other experimental inhibition of DENV [18], possibly by interaction of flavonoids with viral enzymes involved in the ARN synthesis or maturation of polyprotein.

By comparing the extracts obtained at three different temperatures, we observed a higher inhibition of DENV2 replication with those obtained at $60{ }^{\circ} \mathrm{C}$ (Fig. 1a), suggesting the selection and conservation of compounds with anti-dengue properties. The time and temperature of extraction of compounds with pharmacological potential are important

Table 4 Compounds identified in T. officinale fraction 9 by HPLC-PDA-ESI-MS/MS

\begin{tabular}{llllll}
\hline Compound & & tR, min & UVmax, nm & [M-H], m/z & $\begin{array}{l}\text { MS2 - MS3 } \\
\text { Fragment ions, m/z }\end{array}$ \\
\hline 1 & & & 290 & 341 & 179,135 \\
2 & Caffeoyl hexoside & 13.5 & 326 & 353 & 191 \\
3 & 5-O-Caffeoylquinic acid & 20.3 & 322 & 179 & 135 \\
4 & Caffeic acid & 23.5 & 358 & 595 & 463,301 \\
5 & Quercetin diglycoside & 25.2 & 358 & 595 & 463,301 \\
6 & Quercetin diglycoside & 29.9 & 338 & 609 & 285 \\
7 & Luteolin diglycoside & 38.6 & 358 & 309 & 301 \\
8 & Quercetin-3-O-rutinoside & 45.4 & 348 & 593 & 285 \\
9 & Luteolin-7-O-rutinoside & 46.1 & 346 & 447 & 285 \\
10 & Luteolin-7-O-glucoside & 47.5 & 328 & 473 & 311,179 \\
11 & Chicoric acid & 48.4 & 328 & 473 & $311,179,149$ \\
12 & Chicoric acid & 51.7 & 348 & 593 & 285 \\
13 & Luteolin-7-O-rutinoside & 53.2 & 325 & 515 & 353,191 \\
14 & 3,5-di-O-Caffeoylquinic acid & 54.1 & 327 & 515 & $353,179,173$ \\
\hline
\end{tabular}


Table 5 Compounds identified in U. dioica fraction 7 by HPLC-PDA-ESI-MS/MS

\begin{tabular}{|c|c|c|c|c|c|}
\hline \multicolumn{2}{|c|}{ Compound } & \multirow{2}{*}{$\frac{\mathrm{tR}, \mathrm{min}}{15.6}$} & \multirow{2}{*}{$\frac{\text { UVmax, nm }}{320}$} & \multirow{2}{*}{$\frac{[\mathrm{M}-\mathrm{H}], \mathrm{m} / \mathrm{z}}{387}$} & \multirow{2}{*}{$\frac{M S 2 \mathrm{~m} / \mathrm{z}}{163}$} \\
\hline 1 & Coumaroyl derivative & & & & \\
\hline 2 & Sinapoyl derivative & 22.5 & 322 & 433 & 223 \\
\hline 3 & Quercetin-3-O-rutinoside & 43.1 & 352 & 609 & 301 \\
\hline 4 & Quercetin-3-O-hexose & 45.6 & 352 & 463 & 301 \\
\hline 5 & Kaempferol-3-O-hexose & 45.7 & 350 & 447 & 285 \\
\hline 6 & Kaempferitrin & 49.6 & 356 & 577 & 285 \\
\hline 7 & Kaempferol-3-O-hexose & 54.0 & 348 & 447 & 285 \\
\hline
\end{tabular}

parameters to optimize production and lower costs for the overall process. Different authors propose that increasing the temperature in the extraction process promotes increased solubility and the diffusion coefficient of phenolic compounds, provided they do not cause denaturation $[50,51]$.

A similar process occurs with $C$. pulcherrima, the aqueous extracts of this plant contain compounds like quercetin with a broad inhibitory activity on adenovirus 8 and 3 and on herpesviruses [26]. It is possible that the reason for the activity is not a single molecule, but a mixture of them and that could have an effect on different viruses through different mechanisms.

An important parameter to consider is the selectivity index (SI), which ranged from 5.59 and 9.43 for the extracts or fractions. These values are similar to other reports of natural products with some anti-dengue activity $[18,19,47,52,53]$. SI represents the relative effectiveness of a product in inhibiting viral replication compared to inducing cell citotoxicity. High therapeutic index represents a relative low cytotoxicity and high antiviral activity. This parameter is used for in vitro tests, unlike the therapeutic index which is a measurement with a similar meaning, but performed in vivo $[54,55]$.

In our work the aqueous extracts showed less inhibition compared with extracts obtained with methanol, as it was reported previously [42] to assess the inhibitory effect of aqueous and methanol extracts of Hydrocotyle sibthorpioides on the replication of DENV.

Through HPLC-DPA-ESI-MS/MS we identified 11 compounds in the T. officinale F9 and 6 in the $U$. dioica F7. In both fractions, quercetin derivatives were found. Several studies report that quercetin have anti-dengue activity $[18,43,44]$, although the specific mechanisms remain undetermined. However, the interaction of quercetin or its derivatives with the NS2B-NS3 protease $[45,56]$, the envelope (E) protein $[57,58]$ and the NS5 polymerase [59] have been predicted by in silico methods.

On the other hand, luteolin derivatives were found in the $T$. officinale fraction. Luteolin has been reported to have inhibitory activity on several viruses such as enterovirus 71, Coxsackievirus A16 [60] and chikungunya virus
[61]. In recent articles, the interaction of one of the identified compounds, luteolin-7-O-glucoside, and other luteolin derivatives, has been predicted to interact with the NS2/NS3 protease using in silico analysis $[46,56]$. In addition, a very recent study showed that luteolin reduces DENV infection through the inhibition of human furin, which is an enzyme involved in the maturation of the virions, whereby viral particles with a low infectious capacity are produced [53].

Other compounds identified in T. officinale F9 were caffeic acid and caffeoylquinic acid derivatives. These molecules have been shown as inhibitors of some important viruses such as hepatitis B [62], influenza A [63], herpes simplex [64] and more recently, dengue virus [47]. In this last study, Zanello et al., show the effect of two derivatives on the four DENV serotypes.

\section{Conclusions}

It is interesting that analyzed fractions of $T$. officinale and $U$. dioica have several molecules with demonstrated antiviral activity. Recently, an antiretroviral activity (HIV-1) in aqueous extracts of $T$. officinale was identified [24], while other studies have identified an inhibitory effect against yellow fever virus (prototype of Flaviviridae) [65]. Is it possible that different compounds in this plant could have effects against different viruses?

The study of the recognized components present in our factions is determinant to identify the probable anti-dengue molecule and/or their effects on other viruses, including the recent mosquito-borne emerging viruses chikungunya and Zika. It is also necessary to study a formulation of several active compounds in these fractions, searching a probable synergism in the process of inhibition of virus infection. Our group is currently performing these studies.

\footnotetext{
Acknowledgements

María R. Flores-Ocelotl had scholarships from CONACYT and IMSS. Julio

Reyes-Leyva has a research fellowship from Fundación IMSS A.C.
}

\section{Funding}

This work was supported by Consejo Nacional de Ciencia y Tecnología

(CONACYT, SALUD-2012-01-181249, FIS/IMSS/PROT/1084), Redes Temáticas-SEP 2012 México and Funds for Scientific Infrastructure from the Instituto Mexicano del Seguro Social (CTFIS/10RD/12/2011). 


\section{Availability of data and materials}

All data generated or analyzed during this study are included in this published article.

\section{Authors' contributions}

MRFO, FDA, NHRM, JRL and GSL participated in the conception, design and acquisition of funds for the study. MRFO performed the extraction and infection procedures. DAM and MRFO carried out the analysis and interpretation of the HPLC-DAD-ESI/MSn studies. WR, FDA, JRL and DAM made substantial contribution in interpretation of data and revising the manuscript for intellectual content. All authors read and approved the final manuscript.

\section{Ethics approval and consent to participate}

Not applicable.

\section{Consent for publication}

Not applicable.

\section{Competing interests}

The authors declare that they have no competing interests.

\section{Publisher's Note}

Springer Nature remains neutral with regard to jurisdictional claims in published maps and institutional affiliations.

\section{Author details \\ 'Laboratorio de Biología Molecular y Virología, Centro de Investigación Biomédica de Oriente, Instituto Mexicano del Seguro Social, Km 4.5 Carr Federal Atlixco-Metepec, 74360 Metepec, Puebla, México. ${ }^{2}$ Laboratorio de Biotecnología de Productos Naturales, Centro de Investigación Biomédica de Oriente, Instituto Mexicano del Seguro Social, Km 4.5 Carretera Federal Atlixco-Metepec, CP 74360 Metepec, Puebla, México. ${ }^{3}$ Posgrado en Ciencias Químicas, Benemérita Universidad Autónoma de Puebla, Ciudad Universitaria, Avenida San Claudio s/n, Puebla 72570, México. ${ }^{4}$ Laboratorio de Bioquímica, Centro de Química, Instituto de Ciencias, Benemérita Universidad Autónoma de Puebla, Avenida San Claudio s/n, Puebla 72570, México. ${ }^{5}$ Department of Food Science and Technology, Phytochemistry and Healthy Foods Lab, CEBAS-CSIC, Campus Universitario de Espinardo 25, E-30100 Murcia, Spain.}

\section{Received: 6 May 2017 Accepted: 8 March 2018}

\section{Published online: 16 March 2018}

\section{References}

1. Guzman MG, Halstead SB, Artsob H, Buchy P, Farrar J, Gubler D Hunsperger E, Kroeger A, Margolis HS, Martinez E, et al. Dengue: a continuing global threat. Nat Rev Microbiol. 2010;8(12 Suppl):S7-16.

2. Brady OJ, Gething PW, Bhatt S, Messina JP, Brownstein JS, Hoen AG, Moyes CL, Farlow AW, Scott TW, Hay SI. Refining the global spatial limits of dengue virus transmission by evidence-based consensus. PLoS Negl Trop Dis. 2012; 6(8):e1760.

3. Bhatt $S$, Gething PW, Brady OJ, Messina JP, Farlow AW, Moyes CL, Drake JM, Brownstein JS, Hoen AG, Sankoh O, et al. The global distribution and burden of dengue. Nature. 2013;496(7446):504-7.

4. Perera R, Kuhn RJ. Structural proteomics of dengue virus. Curr Opin Microbiol. 2008;11(4):369-77.

5. Lim SV, Rahman MB, Tejo BA. Structure-based and ligand-based virtual screening of novel methyltransferase inhibitors of the dengue virus. BMC Bioinformatics. 2011;12 Suppl 13:S24.

6. Brecher M, Chen H, Li Z, Banavali NK, Jones SA, Zhang J, Kramer LD, Li H. Identification and characterization of novel broad-spectrum inhibitors of the Flavivirus Methyltransferase. ACS Infect Dis. 2015;1 (8):340-9.

7. Whitby K, Pierson TC, Geiss B, Lane K, Engle M, Zhou Y, Doms RW, Diamond MS. Castanospermine, a potent inhibitor of dengue virus infection in vitro and in vivo. J Virol. 2005;79(14):8698-706.

8. Zandi K, Lim TH, Rahim NA, Shu MH, Teoh BT, Sam SS, Danlami MB, Tan KK, Abubakar S. Extract of Scutellaria baicalensis inhibits dengue virus replication. BMC Complement Altern Med. 2013;13:91.

9. Beesetti H, Khanna N, Swaminathan S. Drugs for denque: a patent review (2010-2014). Expert Opin Ther Pat. 2014;24(11):1171-84.
10. Simmons CP, McPherson $K$, Van Vinh Chau N, Hoai Tam DT, Young P, Mackenzie J, Wills B. Recent advances in dengue pathogenesis and clinical management. Vaccine. 2015;33(50):7061-8.

11. Lambrechts $L$, Failloux AB. Vector biology prospects in dengue research. Mem Inst Oswaldo Cruz. 2012;107(8):1080-2.

12. Low JG, Ooi EE, Vasudevan SG. Current status of denque therapeutics research and development. J Infect Dis. 2017;215(suppl_2):S96-S102.

13. Mamedov N. Medicinal plants studies: history, challenges and prospective. Med Aromat Plants. 2012;1:e133.

14. Petrovska BB. Historical review of medicinal plants' usage. Pharmacogn Rev. 2012:6(11):1-5.

15. Dhami N. Trends in Pharmacognosy: a modern science of natural medicines. J Herbal Med. 2013;3(4):123-31.

16. Sanchez I, Gomez-Garibay F, Taboada J, Ruiz BH. Antiviral effect of flavonoids on the dengue virus. Phytother Res. 2000;14(2):89-92.

17. Zandi K, Lani R, Wong PF, Teoh BT, Sam SS, Johari J, Mustafa MR, AbuBakar S. Flavone enhances dengue virus type-2 (NGC strain) infectivity and replication in vero cells. Molecules. 2012;17(3):2437-45.

18. Zandi K, Teoh BT, Sam SS, Wong PF, Mustafa MR, Abubakar S. Antiviral activity of four types of bioflavonoid against dengue virus type-2. Virol J. 2011;8:560.

19. Zandi K, Teoh BT, Sam SS, Wong PF, Mustafa MR, Abubakar S. In vitro antiviral activity of fisetin, rutin and naringenin against dengue virus type-2. J Med Plant Res. 2011;23:5534-9.

20. Aquilar A, Camacho JR, Chino S, Jacquez P, López ME. Plantas medicinales del herbario IMSS: cuadros basicos por aparatos y sistemas del cuerpo humano. Mexico: Instituto Mexicano del Seguro Social; 1994.

21. Ghaima KK, Hashim NM, Ali SA. Antibacterial and antioxidant activities of ethyl acetate extract of nettle (Urtica dioica) and dandelion (Taraxacum officinale). J Appl Pharm Sci. 2013;3(5):96-9.

22. Bisht $\mathrm{S}$, Bhandari S, Bisht NS. Urtica dioica (L): an undervalued, economically important plant. Agric Sci Res J. 2012;2(5):250-2.

23. Yarnell E, Abascal K. Dandelion (Taraxacum officinale and T mongolicum). Integrat Med. 2009:8(2):35-8.

24. Han H, He W, Wang W, Gao B. Inhibitory effect of aqueous dandelion extract on HIV-1 replication and reverse transcriptase activity. BMC Complement Altern Med. 2011;11:112.

25. Baytelman B. De enfermos y curanderos, medicina tradicional en Morelos. Mexico D.F.: Instituto Nacional de Antropología e Historia; 1986.

26. Chiang LC, Chiang W, Liu MC, Lin CC. In vitro antiviral activities of Caesalpinia pulcherrima and its related flavonoids. J Antimicrob Chemother. 2003;52(2):194-8.

27. Andrade-Cetto A, Heinrich M. Mexican plants with hypoglycaemic effect used in the treatment of diabetes. J Ethnopharmacol. 2005:99(3):325-48.

28. Jarald E, Balakrishnan SJ, Jain DC. Diabetes and herbal medicines. Iran J Pharmacol Ther. 2008;7(1):97-106.

29. Alen MM, De Burghgraeve T, Kaptein SJ, Balzarini J, Neyts J, Schols D. Broad antiviral activity of carbohydrate-binding agents against the four serotypes of dengue virus in monocyte-derived dendritic cells. PLoS One. 2011;6(6):e21658.

30. Medina F, Medina JF, Colón C, Vergne E, Santiago GA, Muñoz-Jordán JL. Denque virus: isolation, propagation, quantification, and storage. In: Current protocols in microbiology. Wiley; 2005.

31. Álvarez M, Rodriguez-Roche R, Bernardo L, Morier L, Guzmán G. Improved dengue virus plaque formation on BHK21 and LLCMK2 cells: evaluation of some factors. Dengue Bull. 2005;29:1-9.

32. Palma-Ocampo HK, Flores-Alonso JC, Vallejo-Ruiz V, Reyes-Leyva J, FloresMendoza L. Herrera-Camacho I, Rosas-Murrieta NH, Santos-Lopez G. Interferon lambda inhibits dengue virus replication in epithelial cells. Virol J. 2015;12:150.

33. Estrada-Jimenez T, Millan-Perez Pena L, Flores-Mendoza L, Sedeno-Monge $V$, Santos-Lopez G, Rosas-Murrieta N, Reyes-Carmona S, Teran-Cabanillas E, Hernandez J, Herrera-Camacho I, et al. Upregulation of the suppressors of cytokine signaling 1 and 3 is associated with arrest of phosphorylatedSTAT1 nuclear importation and reduced innate response in denguevirusinfected macrophages. Viral Immunol. 2016;29(2):95-104.

34. Lanciotti RS, Calisher CH, Gubler DJ, Chang GJ, Vorndam AV. Rapid detection and typing of dengue viruses from clinical samples by using reverse transcriptase-polymerase chain reaction. J Clin Microbiol. 1992;30(3):545-51.

35. Diamond MS, Edgil D, Roberts TG, Lu B, Harris E. Infection of human cells by dengue virus is modulated by different cell types and viral strains. J Virol. 2000;74(17):7814-23 
36. Mosmann T. Rapid colorimetric assay for cellular growth and survival: application to proliferation and cytotoxicity assays. J Immunol Methods. 1983;65(1-2):55-63.

37. Muhamad M, Kee LY, Rahman NA, Yusof R. Antiviral actions of flavanoidderived compounds on dengue virus type-2. Int J Biol Sci. 2010;6(3):294-302.

38. Clifford MN, Johnston KL, Knight S, Kuhnert N. Hierarchical scheme for LC-MSn identification of chlorogenic acids. J Agric Food Chem. 2003;51(10):2900-11.

39. Schutz K, Kammerer DR, Carle R, Schieber A. Characterization of phenolic acids and flavonoids in dandelion (Taraxacum officinale WEB. ex WIGG.) root and herb by high-performance liquid chromatography/electrospray ionization mass spectrometry. Rapid Commun Mass Spectrom. 2005;19(2):179-86.

40. Mabry TJ, Markham KR, Thomas MB. The systematic identification of flavonoids. Springer Berlin Heidelberg: Heidelberg; 1970.

41. Cuyckens F, Rozenberg R, de Hoffmann E, Claeys M. Structure characterization of flavonoid O-diglycosides by positive and negative nanoelectrospray ionization ion trap mass spectrometry. J Mass Spectrom. 2001; 36(11):1203-10.

42. Husin F, Chan YY, Gan SH, Sulaiman SA, Shueb RH. The effect of hydrocotyle sibthorpioides Lam. Extracts on in vitro dengue replication. Evid Based Complement Alternat Med. 2015;2015:596109.

43. Chiow KH, Phoon MC, Putti T, Tan BK, Chow VT. Evaluation of antiviral activities of Houttuynia cordata Thunb. extract, quercetin, quercetrin and cinanserin on murine coronavirus and dengue virus infection. Asian Pac J Trop Med. 2016;9(1):1-7.

44. de Sousa LR, Wu H, Nebo L, Fernandes JB, da Silva MF, Kiefer W, Kanitz M, Bodem J, Diederich WE, Schirmeister T, et al. Flavonoids as noncompetitive inhibitors of dengue virus NS2B-NS3 protease: inhibition kinetics and docking studies. Bioorg Med Chem. 2015;23(3):466-70.

45. Senthilvel P, Lavanya P, Kumar KM, Swetha R, Anitha P, Bag S, Sarveswari S, Vijayakumar V, Ramaiah S, Anbarasu A. Flavonoid from Carica papaya inhibits NS2B-NS3 protease and prevents dengue 2 viral assembly. Bioinformation. 2013;9(18):889-95.

46. Dwivedi VD, Tripathi IP, Bharadwaj S, Kaushik AC, Mishra SK. Identification of new potent inhibitors of dengue virus NS3 protease from traditional Chinese medicine database. Virusdisease. 2016;27(3):220-5.

47. Zanello PR, Koishi AC, Rezende Junior Cde O, Oliveira LA, Pereira AA, de Almeida MV, Duarte dos Santos CN, Bordignon J. Quinic acid derivatives inhibit dengue virus replication in vitro. Virol J. 2015;12:223.

48. Seo SW, Koo HN, An HJ, Kwon KB, Lim BC, Seo EA, Ryu DG, Moon G, Kim $\mathrm{HY}$, Kim HM, et al. Taraxacum officinale protects against cholecystokinininduced acute pancreatitis in rats. World J Gastroenterol. 2005;11(4):597-9.

49. Rodriguez-Fragoso L, Reyes-Esparza J, Burchiel SW, Herrera-Ruiz D, Torres E. Risks and benefits of commonly used herbal medicines in Mexico. Toxicol Appl Pharmacol. 2008;227(1):125-35.

50. Khoddami A, Wilkes MA, Roberts TH. Techniques for analysis of plant phenolic compounds. Molecules. 2013;18(2):2328-75.

51. Robards K. Strategies for the determination of bioactive phenols in plants, fruit and vegetables. J Chromatogr A. 2003;1000(1-2):657-91.

52. Teixeira RR, Pereira WL, Oliveira AF, da Silva AM, de Oliveira AS, da Silva ML, da Silva CC, de Paula SO. Natural products as source of potential dengue antivirals. Molecules. 2014;19(6):8151-76.

53. Peng M, Watanabe S, Chan KW, He Q, Zhao Y, Zhang Z, Lai X, Luo D, Vasudevan SG, Li G. Luteolin restricts dengue virus replication through inhibition of the proprotein convertase furin. Antivir Res. 2017;143:176-85.

54. Food and Drug Administration. Guidance for industry. Antiviral product development—conducting and submitting virology studies to the agency 2006. http://www.fda.gov/OHRMS/DOCKETS/98fr/05d-0183-gdl0002-01.pdf.

55. Pezzuto JM, Angerhofer CK, Mehdi H. In vitro models of human disease states. Stud Nat Prod Chem. 1997;20:507-60.

56. Ramana MMV, Ranade PB, Betkar RR, Nimkar AP, Mundhe BC, Bhar S Flavones: Potential antidengue targets in silico approach. J Chem Pharm Res. 2015;7(8):585-91.

57. Mir A, Ismatullah H, Rauf S, Niazi UHK. Identification of bioflavonoid as fusion inhibitor of dengue virus using molecular docking approach. Informatics Medicine Unlocked. 2016;3:1-6.

58. Manikandan P, Muthu selvam A, Manibalan S. Small molecules screening against type 2 dengue virus envelope protein (DenV e) from phyto antiviral ligands-an in silico analysis. Asian J Med Pharm Sci. 2014;2(2):143-8.

59. Anusuya S, Gromiha MM. Quercetin derivatives as non-nucleoside inhibitors for dengue polymerase: molecular docking, molecular dynamics simulation, and binding free energy calculation. J Biomol Struct Dyn. 2017;35(13):2895902.

60. Xu L, Su W, Jin J, Chen J, Li X, Zhang X, Sun M, Sun S, Fan P, An D, et al. Identification of luteolin as enterovirus 71 and coxsackievirus A16 inhibitors through reporter viruses and cell viability-based screening. Viruses. 2014;6(7): 2778-95.

61. Murali KS, Sivasubramanian S, Vincent S, Murugan SB, Giridaran B, Dinesh S, Gunasekaran P, Krishnasamy K, Sathishkumar R. Anti-chikungunya activity of luteolin and apigenin rich fraction from Cynodon dactylon. Asian Pac J Trop Med. 2015;8(5):352-8.

62. Wang GF, Shi LP, Ren YD, Liu QF, Liu HF, Zhang RJ, Li Z, Zhu FH, He PL, Tang W, et al. Anti-hepatitis B virus activity of chlorogenic acid, quinic acid and caffeic acid in vivo and in vitro. Antivir Res. 2009;83(2):186-90.

63. Utsunomiya $H$, Ichinose M, Ikeda K, Uozaki M, Morishita J, Kuwahara T, Koyama AH, Yamasaki $\mathrm{H}$. Inhibition by caffeic acid of the influenza a virus multiplication in vitro. Int J Mol Med. 2014;34(4):1020-4.

64. Ikeda K, Tsujimoto K, Uozaki M, Nishide M, Suzuki Y, Koyama AH, Yamasaki $\mathrm{H}$. Inhibition of multiplication of herpes simplex virus by caffeic acid. Int J Mol Med. 2011;28(4):595-8.

65. Rodríguez-Ortega M, Chumpitaz Z, Ríos S, Méndez M, Méndez J, Cabrera G. Actividad antiviral contra el virus de la fiebre amarilla, cepa vacunal 17D, de extractos de hojas de Taraxacum officinale GH Weber ex Wiggers. Bol Latinoam Caribe Plant Med Arom. 2013;12(4):346-55.

\section{Submit your next manuscript to BioMed Central and we will help you at every step:}

- We accept pre-submission inquiries

- Our selector tool helps you to find the most relevant journal

- We provide round the clock customer support

- Convenient online submission

- Thorough peer review

- Inclusion in PubMed and all major indexing services

- Maximum visibility for your research

Submit your manuscript at www.biomedcentral.com/submit
Biomed Central 